\title{
Improvement of Laboratory Services When using Sample Preparation in Microwave System
}

\section{IJCRR}

Section: Healthcare

Sci. Journal Impact

Factor: 6.1 (2018)

ICV: 90.90 (2018)

(c) (i) (3)

Copyright@IJCRR

\section{Maksim Rebezov' ${ }^{1}$ Anna Chuprakova ${ }^{2}$, Lyudmila Tretyak ${ }^{3}$, Anton Nesterenko ${ }^{4}$, Tatiana Zaitseva5, Inna Trofimova6, Ekaterina Redina7, Maria Babaeva8, Olga Orlovtseva9}

\begin{abstract}
V. M. Gorbatov Federal Research Center for Food Systems of Russian Academy of Sciences, Moscow, Russian Federation; Prokhorov General Physics Institute of the Russian Academy of Science, Moscow, Russian Federation; K.G. Razumovsky Moscow State University of technologies and management (the First Cossack University), Moscow, Russian Federation; ${ }^{2}$ Center for Hygiene and Epidemiology of the Chelyabinsk Region in Magnitogorsk and Agapovsky, Kizilsky, Nagaybaksky, Verkhneuralsky Districts, Magnitogorsk, Russian Federation; ${ }^{3} \mathrm{Orenburg}$ State University, Orenburg, Russian Federation; ${ }^{4}$ Kuban State Agrarian University, Krasnodar, Russian Federation; ${ }^{5}$ Nosov Magnitogorsk State Technical University, Magnitogorsk, Russian Federation; ${ }^{6,7,89} \mathrm{~K}$.G. Razumovsky Moscow State University of technologies and management (the First Cossack University), Moscow, Russian Federation.
\end{abstract}

\section{ABSTRACT}

Introduction: In the laboratory activity, the quality of testing analysis for determination of the toxic and heavy metals is considered as its ability to ensure the test validity. Improvement of measurement methods, sample preparation for analysis, the introduction of new equipment to improve the quality indicators of services are the most relevant tasks in the activities of testing laboratories.

Materials and Methods: With the purpose of comparison of results received by operation on atomic-absorption spectrometer "Quantum-2AT" with use of microwave laboratory system PLP(Pech Laboratory Probopodgotovka)-01M and at sample preparation according to Government Standards(GOST)-26929, four different groups of products were chosen as working samples. These products are fish, bread, milk, meat.

Results: The analysis of results of research of samples on the content of lead and cadmium by their determination on atomic absorption spectrometer "Quantum-2AT" with use of microwave laboratory system PLP(Pech Laboratory Probopodgotovka)-01M and sample preparation according to Government Standards(GOST)-26929 is presented. The analysis of the performed studies allowed estimating the time spent on one study taking into account the implementation of different types of sample preparation for analysis. It is established that higher accuracy indicators are achieved in case of microwave decomposition using microwave laboratory system PLP-01M. It is necessary to note a higher level of automation of the sample preparation process in case of application of microwave laboratory system PLP-01M in comparison with the traditional algorithm of sample preparation for analysis according to GOST 26929.

Conclusion: It is shown that the validity of the results is determined by several factors: the methods used, the equipment and reagents used, the competence of the personnel, the procedure of internal laboratory control. Using microwave laboratory system PLP-01M for the decomposition of samples before atomic absorption analysis has improved quantitative indicators of quality of the analysis.

Key Words: Safety; Quality; Control; Microwave decomposition, Xenobiotics, Lead, Cadmium; Indicators of accuracy

\section{INTRODUCTION}

The competitiveness of analytical laboratories, as well as of any organization, is determined by the quality of services provided, regardless of the specifics of its activities. Because quality is an economic category, the ratio "achieved indicators of quality of measurement (testing) results/price of the service, expended on quality indicators maintenance by the laboratory" is of key importance.

The quality of the provided service is closely connected with the competence of the laboratory. Laboratory competence is a proven ability to apply knowledge and skills in practice (under Group of standards for Russia GOST R ISO

\section{Corresponding Author:}

Dr. Maksim Rebezov, V.M. Gorbatov Federal Research Center for Food Systems of Russian Academy of Sciences, Moscow, Russian Federation; Email: maksim.rebezov147@gmail.com

ISSN: 2231-2196 (Print)

Received: 22.06 .2020
ISSN: $0975-5241$ (Online)

Revised: 17.07 .2020
Accepted: 07.08 .2020
Published: 22.08 .2020 
9000 which is National Standard of Russia). The quality of provided services and the competence of the laboratory determines its competitiveness. In the activity area of laboratories, quality is considered as the ability of laboratories to provide testing services, namely to provide reliable test results, while ensuring the required accuracy of measurements (tests). The following factors influence the accuracy of the results: the methods used, the equipment and reagents used, the competence of the personnel, the procedure of internal laboratory control. The improvement of measuring methods, preparation of the sample for analysis, new equipment launching, which allows improving the quality indicators of the provided services, are the most actual tasks in the activity of testing laboratories.

\section{MATERIAL AND METHODS}

In this paper the analysis of the results of lead and cadmium content determined by the atomic absorption spectrometer "Quantum-2AT" with the use of microwave laboratory sys- tem PLP-01M and in case of dry ashing under GOST 26929 "Mineralization of food samples to determine the content of toxic elements". To reduce the time of long and labourintensive phase of sample mineralization, the microwave decomposition of the sample was carried out in PLP-01M, where the organic matrix was destroyed under the influence of high temperature, pressure and microwave fields in hermetic vessels following the instruction of microwave laboratory furnace PLP-01M (manufacturer "Ural-Gefest"). For comparison of results obtained at the atomic-absorption spectrometer "Quantum-2AT" with the use of microwave laboratory system PLP-01M and at sample preparation following GOST 26929, four different groups of products were selected on the working samples, most fully covering the range of results obtained in studies. The following testing samples were selected: river fish, wheat bread, cow's milk and beef. Standard samples of lead ion solution composition, cadmium, given in Table 1, were chosen as materials for the tests.

Table 1: Characteristics of certified reference samples of lead and cadmium ion solution composition

\begin{tabular}{lcccc}
$\begin{array}{l}\text { Name of the standard sample (by } \\
\text { GOST 8.315-2019) }\end{array}$ & $\begin{array}{c}\text { State standard } \\
\text { sample number }\end{array}$ & $\begin{array}{c}\text { Type Approval } \\
\text { Certificate }\end{array}$ & $\begin{array}{c}\text { Tested value of the } \\
\text { sample, mg/cm }\end{array}$ & $\begin{array}{l}\text { Producer } \\
\text { State standard sample of lead ion } \\
\text { solution composition }\end{array}$ \\
$\begin{array}{l}\text { State standard sample of cadmium } \\
\text { ion solution composition }\end{array}$ & 7252 & № 4347 & $\begin{array}{l}\text { Ural Research Institute of } \\
\text { Metrology }\end{array}$ \\
\hline
\end{tabular}

A sampling of the selected food products was carried out by GOST 26929 and the instructions of microwave laboratory oven PLP-01M "Ural-Gefest". The volume of the sample taken for analysis is given in Table 2 .

Table 2: Quantity of sample taken for analysis

\begin{tabular}{|c|c|c|c|c|}
\hline \multirow[t]{3}{*}{ Product category (samples) } & \multicolumn{4}{|c|}{ Sample weight in $\mathrm{g}$ (sample volume in $\mathrm{cm}$ ) } \\
\hline & \multicolumn{2}{|c|}{ Sample preparation according to GOST 26929} & \multicolumn{2}{|c|}{ Microwave decomposition on PLP-o1M } \\
\hline & $\mathbf{P b}($ Lead $)$ & Cd(Cadmium) & $\mathbf{P b}$ & Cd \\
\hline beef & 10 & 10 & 2 & 2 \\
\hline freshwaterfish & 10 & 5 & 2 & 2 \\
\hline cow'smilk & 100 & 50 & 2 & 2 \\
\hline whitebread & 20 & 15 & 2 & 2 \\
\hline
\end{tabular}

The result of the control $\mathrm{K}$ procedure was calculated by the formula:

Кк $=\mathrm{Xcp}(\mathrm{n})+$ д $-\mathrm{Xcp}(\mathrm{n})-\mathrm{Cд}, \mathrm{mg} / \mathrm{kg}$

where Сд - additive value, $\mathrm{mg} / \mathrm{kg}$;

$\mathrm{Xcp}(\mathrm{n})+д-$ concentration of a determining element in an average work sample with a defined additive of a determining element, $\mathrm{mg} / \mathrm{kg}$;
Xcp (n) - concentration of the measuring element in the average work sample, $\mathrm{mg} / \mathrm{kg}$.

The $\mathrm{K}$ control standard is calculated by the formula:

$$
K=\sqrt{\left(\Delta \pi_{X n+\partial}\right)^{2}+\left(\Delta \pi_{X n}\right)^{2}}, \mathrm{mg} / \mathrm{kg}
$$

where $\pm \Delta л-$ measurement error characteristic corresponding to the content of the element to be determined in the additive sample, calculated by the formula: 


$$
\Delta л=0,01 \times \delta л \times X, \mathrm{mg} / \mathrm{kg}
$$

$\pm \Delta л-$ measurement error characteristic corresponding to the content of the element to be determined in the additive sample, calculated by the formula:

$$
\Delta л=0,01 \times \delta л \times \mathrm{Xn}, \mathrm{mg} / \mathrm{kg}
$$

$\pm \delta л-$ the relative value of the measurement error characteristic, established during the procedure implemented in the laboratory and ensured by controlling the stability of the analysis results:

$$
\delta л=0,84 \times \delta, \%
$$

$\pm \delta$ - method accuracy index, $\%$.

The procedure of analysis was considered satisfactory when the condition was met:

$$
\mid \text { Кк } \mid \leq \kappa
$$

\section{RESULTS}

Independent measurement results were obtained by the same method on the same test objects, in the same labo- ratory, by the same operator, using the same equipment - atomic absorption spectrometer "Quantum-2AT", within a short period, i.e. conditions of repetition were ensured. To check the reproducibility of the measurement results, the studies were performed by different operators using the same equipment on different days, i.e. intermediate (intra-laboratory) precision conditions were met. Within 30 working days, the selection of observation results and analysis of data obtained during the work on the atomic absorption spectrometer "Quantum-2AT" with the use of microwave laboratory system PLP-01M and sample preparation by GOST 26929. The average values obtained under conditions of repeatability were registered in the intermediate table. The accuracy control was carried out by the method of additions: at the stage of sample preparation the additive of the determined substance - lead and cadmium - was added. Under intermediate precision conditions, five mean values for each product type were obtained: for samples with and without the addition of a defined element. To evaluate the metrological characteristics, an average of five average values for each product type was recorded in

\begin{tabular}{|c|c|c|c|c|c|c|}
\hline \multirow[t]{2}{*}{ Sample } & \multirow[t]{2}{*}{$\begin{array}{l}\text { Determining } \\
\text { element }\end{array}$} & \multicolumn{2}{|c|}{ Mean value, $\mathrm{mg} / \mathrm{kg}$} & \multirow[t]{2}{*}{$\begin{array}{c}\text { Additive } \\
\text { amount, mg/ } \\
\text { kg }\end{array}$} & \multicolumn{2}{|c|}{$\begin{array}{l}\text { Control measurement result } \\
\text { of the sample with additive, } \\
\mathrm{mg} / \mathrm{kg}\end{array}$} \\
\hline & & GOST & PLP-o1M & & GOST & PLP-oiM \\
\hline \multirow[t]{2}{*}{ Fresh water fish } & $\mathrm{Pb}($ Lead $)$ & 0.0686 & 0.0734 & 0.05 & 0.1158 & 0.1228 \\
\hline & Cd(Cadmium) & 0.0444 & 0.0522 & 0.03 & 0.0728 & 0.0826 \\
\hline \multirow[t]{2}{*}{ White bread } & $\mathrm{Pb}$ & 0.0136 & 0.0172 & 0.015 & 0.0248 & 0.0284 \\
\hline & $\mathrm{Cd}$ & 0.0342 & 0.0400 & 0.015 & 0.0438 & 0.0528 \\
\hline \multirow[t]{2}{*}{ Cow's milk } & $\mathrm{Pb}$ & 0.0304 & 0.0342 & 0.02 & 0.0456 & 0.0498 \\
\hline & $\mathrm{Cd}$ & 0.00854 & 0.01056 & 0.01 & 0.01674 & 0.018832 \\
\hline \multirow[t]{2}{*}{ Beef } & $\mathrm{Pb}$ & 0.3180 & 0.3360 & 0.10 & 0.4060 & 0.4280 \\
\hline & $\mathrm{Cd}$ & 0.0334 & 0.0426 & 0.03 & 0.0590 & 0.0694 \\
\hline
\end{tabular}
the final table 3.

Table 3: Comparative characteristics of determination of lead and cadmium content based on various sample preparation types

The result of the control procedure $\mathrm{K}$ and the control standard $\mathrm{K}$ were calculated according to formulas 1, 2 considering the calculations according to formulas $3,4,5$. Also, compliance with the comparison condition according to Formula
6 was checked. Tables 4 and 5 summarize the report on the quality control procedure for the implementation of the additive method analysis.

Table 4: The results of the control of the procedure of analysis using the additive method (testing of samples for lead content)

\begin{tabular}{lccc} 
& GOST 26929 & & Using PLP-01M \\
Кк & K & КK & K \\
-0.0028 & 0.0204 & -0.0006 & 0.0216 \\
-0.0038 & 0.0043 & -0.0038 & 0.0050 \\
-0.0048 & 0.0083 & -0.0044 & 0.0091 \\
-0.0120 & 0.0780 & -0.0080 & 0.0823 \\
\hline
\end{tabular}


Table 5: The results of the control of the procedure of analysis using the additive method (testing of samples for cadmium content)

\begin{tabular}{lccc} 
GOST 26929 & \multicolumn{3}{c}{ Using PLP-01M } \\
KK & K & KK & K \\
-0.0016 & 0.0086 & 0.0004 & 0.0098 \\
-0.0054 & 0.0056 & -0.0022 & 0.0067 \\
-0.0018 & 0.0019 & -0.0017 & 0.0022 \\
-0.0044 & 0.0068 & -0.0032 & 0.0082 \\
\hline
\end{tabular}

The analysis of the conducted tests made it possible to establish the time spent on performance of one test taking into account realization of various types of preparation of the sample for the analysis, the obtained data are summarized in tables 6,7 .

\section{Table 6: Time spent on one test}

\begin{tabular}{|c|c|c|}
\hline \multirow[t]{2}{*}{ Name of work } & \multicolumn{2}{|c|}{ Time allowance, $\mathbf{h}$} \\
\hline & $\begin{array}{l}\text { Sample } \\
\text { preparation } \\
\text { by GOST } \\
26929\end{array}$ & $\begin{array}{l}\text { Microwave } \\
\text { decompo- } \\
\text { sition on } \\
\text { PLP-o1M }\end{array}$ \\
\hline Sample collection and registra- & 0.1 & 0.1 \\
\hline journal entries & 0.2 & 0.2 \\
\hline Taking the awning & 0.1 & 0.1 \\
\hline Reagent preparation & 0.2 & 0.2 \\
\hline Sample Mineralization & 2.2 & - \\
\hline $\begin{array}{l}\text { Microwave sample decomposi- } \\
\text { tion in microwave laboratory } \\
\text { system PLP-o1M }\end{array}$ & - & 1.2 \\
\hline $\begin{array}{l}\text { Preparation of the device } \\
\text { for operation, construction/ } \\
\text { refinement of the graduation } \\
\text { chart }\end{array}$ & 0.4 & 0.4 \\
\hline $\begin{array}{l}\text { Performing sample analysis on } \\
\text { atomic absorption spectrom- } \\
\text { eter "Quantum-2AT" }\end{array}$ & 0.11 & 0.11 \\
\hline $\begin{array}{l}\text { Conducting internal labora- } \\
\text { tory control, making calcula- } \\
\text { tions, results from registration }\end{array}$ & 0.3 & 0.3 \\
\hline Preparation of utensils & 0.3 & 0.3 \\
\hline Document Processing & 0.3 & 0.3 \\
\hline
\end{tabular}

Table 7: Calculation of net profit with the application of microwave laboratory system PLP-o1M (in Russian rubles)

\begin{tabular}{lc} 
Name of Items & Expenses \\
Profit before tax of one sample & 156.86 \\
Net profit per sample & 90.75 \\
Annual net profit in laboratory & 1456989.56 \\
\hline
\end{tabular}

The capital investment for the introduction of new equipment is $1,917,790$ rubles for the atomic absorption spectrometer "Kvant-2AT" with the application of the microwave laboratory-tor system PLP-01M (introduced "Kvant-2AT" and PLP-01M simultaneously). The total cost of testing, taking into account the capital costs of the introduction of the new equipment will be 4,456,713.53 rubles. The payback period of the "Quantum-2AT" PPL-01M capital investment is 1 year 9 months and 7 days. To reimburse the capital costs for the introduction of the new equipment of the testing laboratory it is necessary to perform 28,412 tests.

\section{DISCUSSION}

Based on the results of the control evaluation of the measurement procedure using lead and cadmium control samples, the analysis procedure is considered satisfactory.

However, it was found that the best accuracy data are achieved by microwave decomposition (using microwave laboratory system PLP-01M). The introduction of the microwave laboratory system PLP-01M will be beneficial if the performance of the new equipment meets the laboratory's needs in terms of the number of tests. Application of microwave laboratory system PLP-01M will allow reducing the time of sample preparation in 19,5 times, and expenses item on "Raw materials and basic materials" at conducting one research will be reduced by 2,6 times. It is established that the reduction of the sample portion in case of microwave decomposition up to $2 \mathrm{~g}$ will reduce the number of reagents used by 3.7 times. It is necessary to note the higher level of automation of the process of sample preparation in case of application of microwave laboratory system PLP-01M in comparison with the traditional algorithm of sample preparation, providing various methods of mineralization according to GOST 26929.

\section{CONCLUSION}

The use of microwave laboratory system PLP-01M for sample decomposition has a significant impact on quantitative indicators of service quality, namely improvement of intralaboratory control indicators, service delivery time is signifi- 
cantly reduced, the accuracy of testing and, consequently, the reliability of test results increases and the costs of the reagents used are reduced.

\section{ACKNOWLEDGEMENTS}

Authors acknowledge the immense help received from the scholars whose articles are cited and included in references to this manuscript. The authors are also grateful to authors/ editors/publishers of all those articles, journals and books from where the literature for this article has been reviewed and discussed.

Conflict of interests: Authors have declared that no conflict of interests exists.

Funding Source: None

\section{REFERENCES}

1. Rebezov M, Chuprakova A, Zinina O, Maksimyuk N, Abuova A. Assessment of methods for researching Xenobiotics (Monograph). Almaty: Epigraph. 2019;1-204.

2. Akhmetova S, Suleimenova M, Rebezov M. Mechanism of improvement of business processes management system for food production: the case of meat products enterprise. Entrepreneurship and sustainability issues.2019; 7(2): 1015-1035.

3. Osintseva D, Osintsev E, Rebezov M, Prokhasko L, Seilgazina S, Kurmanbayev S, Nurzhumanova Z, YessimbekovZh, Voytsekhovskiy V, Maksimiuk N, Zalilov R.Ozonation and microwave treatments as new pest management methods for grain crop cleaning and Disinfection. Annual Research \& Review in Biology.2017; 20(5); 1-6.

4. Cherfi A, Abdoun S, Gaci O. Food survey: levels and potential health risks of chromium, lead, zinc and copper content in fruits and vegetables consumed in Algeria. Food and Chemical Toxicology. 2014; 70: 48-53.

5. Singh BR, Gupta SK, Azaizeh H, Shilev S, Sudre D, Song WY, Martinoia E, Mench M. Safety of food crops on land contaminated with trace elements. J. Sci. Food Agric. 2011; 91 (8): 1349-1366.

6. Ali MM, Ali ML, Proshad R, Islam S, Rahman Z, Tusher TR, Kormoker T, Al MA. Heavy metal concentrations in commercially valuable fishes with health hazard inference from Karnaphuliriver, Bangladesh. Human and Ecological Risk Assessment: An Int.J. 2019;1-17

7. Mourya A, Mazumdar B, Sinha SK. Determination and quantification of the heavy metal ion by electrochemical method. Journal of Environmental Chemical Engineering. 2019; 7 (6): 103459.

8. Kuramshina N, Rebezov M, Kuramshin E, Tretyak L, Topuria G, Kulikov D, Evtushenko A, Harlap S, Okuskhanova E. Heavy metals content in meat and milk of Orenburg region of Russia.
International Journal of Pharmaceutical Research.2019; 11(1): 1301-1305.

9. Zykova I, Maksimuk N, Rebezov M, Kuznetsova E, Derkho M, Sereda T, Kazhibayeva G, Somova Yu, Zaitseva T Interaction between heavy metals and microorganisms during wastewater treatment by activated sludge. ARPN Journal of Engineering and Applied Sciences.2019; 14(11): 2139-2145.

10. Kuramshina N, Rebezov M, Kuramshin E, Krasnogorskaya N, Tretyak L, Somova Yu, Dolmatova I, Zaitseva T, Grigoryeva I, Bakirova L. Heavy Metals Contamination of Soil in Urban Areas of Southern Ural Region of Russia. International Journal of Engineering and Technology.2018; 7(4.42): 14-18.

11. Tourani S, Behvandi A, Aghajari A, Aghajari N. Adsorption of heavy metal ions from aqueous solutions using metal organic frameworks: kinetic and thermodynamic study. Desalination and Water Treatment. 2019; 162: 193-206.

12. Okuskhanova E, Smolnikova F, Kassymov S, Zinina O, Mustafayeva A, Rebezov M, RebezovYa, Tazeddinova D, Galieva Z, Maksimiuk N. Development of minced meatball composition for the population from the unfavourable ecological regions. Annual Research and Review in Biology, 2017; 13(3): 1-9.

13. Zykova I, Rebezov M, Maksimiuk N, Kuramshina N. The Interaction of Metals with Humic Acid of Activated Sludge and Biological Treatment Facilities Sludge. International Journal of ChemTech Research.2016; 9(3): 372-378.

14. Kaushik A, Kansal A, Santosh M, Kumari S, Kaushik CP. Heavy metal contamination of river Yamuna, Haryana, India: assessment by metal enrichment factor of the sediments. Journal of Hazardous Materials. 2009; 164 (1): 265-270.

15. Srut M, Menke S, Sommer S, Höckner M. Earthworms and cadmium - heavy metal resistant gut bacteria as indicators for heavy metal pollution in soils? Ecotoxicology and Environmental Safety. 2019; 171: 843-853.

16. Assenova B, Okuskhanova E, Rebezov M, Korzhikenova N, YessimbekovZh, Dragoev S. Trace and toxic elements in the meat of maral (red deer) grazing in Kazakhstan. Res J Pharm Biol Chem Sci.2016; 7(1): 1425-1433.

17. Mansour SA. Monitoring and health risk assessment of heavy metal contamination in food. Practical Food Safety: Contemporary Issues and Future Directions.2014; 235-255.

18. Yang ZY. To study the activity of palladium used as modifier under microwave decomposition and atomic absorption spectrometry with graphite furnace for the determination of trace elements in food products. Chinese Journal of Spectroscopy Laboratory. 2005; 22 (3): 607-617.

19. Okuskhanova E, Assenova B, Rebezov M, YessimbekovZh, Kulushtayeva B, Zinina O, Stuart M. Mineral composition of deer meat pate. Pakistan Journal of Nutrition.2016; 15(3): 217-222.

20. Barbosa JTP, Korn MGA, Santos CMM, Flores EMM, Peralva VN, Korn M, Nóbrega JA. Microwave-assisted diluted acid digestion for trace element analysis of edible soybean products. Food Chemistry. 2015; 175: 212-217.

21. Lu H, Lu X, Ma L, Cui Y, Wang J, Zhao M. Microwave cleavage for the determination of lead in milk powder by atomic fluorescence spectrometry and mass spectrometry with induction plasma. Journal of Chinese Mass Spectrometry Society. 2004; 25: 9-10. 